\title{
Community Structure of Coral Reefs in Pulau Mertang, Johor, Malaysia
}

\author{
(Struktur Komuniti Terumbu Karang di Pulau Mertang, Johor, Malaysia)
}

\author{
MOHAMAD SAUPI ISMAIL \& MEI LING KHOO*
}

\section{ABSTRACT}

A study was conducted at nine sites around Pulau Mertang using point intercept transect method to determine the coral community of the islands. The results showed the reefs around Pulau Mertang were in good condition with an average live coral cover of $51.0 \pm 2.35 \%$, which is higher than the average live coral cover for Malaysia (42.5\%). Hard corals were found monopolizing the benthic fauna along all transects. A total of 25 different genera from 12 families of scleractinian coral were observed during this survey. The dominant genera found at Pulau Mertang are Acropora (41.26 $\pm 20.88 \%)$ and Montipora ( $14.24 \pm 21.57 \%)$, while other sessile life form was dominated by zoanthids $(7.59 \pm 11.92 \%)$. The percentage cover of the abiotic component of transect was dominated by dead corals (15.19 $\pm 2.26 \%)$. Coral genus diversity was highest at Pulau Mertang Barat $\left(H^{\prime}=2.24\right)$, followed by Pulau Mertang Timur $\left(H^{\prime}=1.71\right)$ and Pulau Mertang Tengah $\left(H^{\prime}=1.56\right)$. Most reefs in Pulau Mertang are classified as C4 categories and all islands show low values of mortality index $(M I=0.23)$. High coral live cover, diversity $\left(H^{\prime}\right)$, conservation class $(C 4)$ and low mortality index and domination by branching and tabular Acropora are attributes of a healthy reef. Therefore, it is concluded that the reefs around Pulau Mertang were still in good condition and healthy. From an ecological point of view, it is the closest representation of an undisturbed reef of a non-marine park island in Johor. Thus, this study forms an initial step in understanding the reef community and provides a basis for future observations on the marine ecosystem of Pulau Mertang.

Keywords: Coral community; coral cover; coral diversity; genera richness; Pulau Mertang

\section{ABSTRAK}

Suatu kajian di sembilan kawasan sekitar Pulau Mertang telah dijalankan dengan menggunakan kaedah transek silangan titik untuk menentukan komuniti karang pulau tersebut. Hasil kajian menunjukkan bahawa terumbu di sekitar Pulau Mertang adalah di dalam keadaan baik dengan purata litupan karang hidup sebanyak $51.0 \pm 2.35 \%$, lebih tinggi berbanding purata litupan karang untuk Malaysia (42.5\%). Karang keras didapati memonopoli hidupan bentik di kesemua transek. Sejumlah 25 genus daripada 12 famili karang skleraktin ditemui semasa kajian ini. Secara amnya, genus dominan yang ditemui di Pulau Mertang ialah genus Acropora (41.26 $\pm 20.88 \%$ ) dan Montipora (14.24 $\pm 21.57 \%$ ), manakala hidupan sesil lain didominasikan oleh zoantid $(7.59 \pm 11.92 \%)$. Peratus litupan komponen abiotik didominasikan oleh karang mati (15.19 $\pm 2.26 \%)$. Kepelbagaian genus karang didapati paling tinggi di Pulau Mertang Barat $\left(H^{\prime}=2.24\right)$, diikuti oleh Pulau Mertang Timur $\left(H^{\prime}=1.71\right)$ dan Pulau Mertang Tengah $\left(H^{\prime}=1.56\right)$. Kebanyakan terumbu karang Pulau Mertang dikelaskan dalam kategori C4 dan kesemua pulau memberi bacaan nilai indeks kematian yang rendah (MI = 0.23). Liputan karang, kepelbagaian ( $\left.H^{\prime}\right)$ dan status kelas pemuliharaan yang tinggi (C4), serta indeks kematian yang rendah dan dominasi karang Acropora merupakan ciri terumbu yang sihat. Oleh itu, disimpulkan bahawa terumbu karang di sekitar Pulau Mertang berada dalam keadaan baik dan sihat. Terumbu Pulau Mertang adalah penting daripada sudut ekologi memandangkan ia mewakili terumbu yang tidak diganggu di luar kawasan taman laut Johor. Justeru, kajian ini merupakan langkah awal di dalam memahami komuniti terumbu di samping menyediakan maklumat asas berkenaan ekosistem marin di Pulau Mertang.

Kata kunci: Kekayaan genus; kepelbagaian karang; komuniti karang; liputan karang; Pulau Mertang

\section{INTRODUCTION}

Coral reefs are complex ecosystem with high biological diversity that provides coastal protection, substantial economic benefits through tourism industries and resources for food and pharmaceutical supplies (Costanza et al. 2014; Mustapha et al. 2014). Despite their importance to the nature, it is unfortunate that coral reefs around the world have been declining due to environmental stresses caused by natural causes and human activities (Jordan et al. 2009).
Coral reefs are very fragile to persistent stresses generated by humans, where small islands in open seas are the most vulnerable (Chou et al. 1994). The Malaysian waters comprise of approximately 398 scleractinian coral species identified, which is more than $80 \%$ of the number of corals species identified in the 'Coral Triangle' and is reckoned as one of the most extensive coral diversity areas (Affendi \& Rosman 2012; Akmal et al. 2014; Harborne et al. 2000; Huang et al. 2015). Regrettably, all reefs in Malaysia are 
under high anthropogenic threats (Kimura et al. 2014). Reef Check Malaysia (2018) reported that the key threats facing coral reefs in Peninsular Malaysia are development and tourism related, with most impacts arising from land-based pollution, sewage pollution, land use change or direct impacts (boats, anchors, users). Fortunately, most reefs could recover with proper management, and such comprehensive management requires monitoring of reefs to allow assessment of their present state, health and threats, and how these change over time, in an effort to ensure the conservation and sustainability of coral reef ecosystems (Beenaerts \& Berghe 2005; Shahbudin et al. 2016).

Pulau Mertang comprises of three small rocky islets $\left(>0.04 \mathrm{~km}^{2}\right.$ ); Pulau Mertang Timur, Pulau Mertang Tengah and Pulau Mertang Barat, lying close together with small beaches edged by coastal vegetation (Grismer et al. 2006). They are located approximately $15 \mathrm{~km}$ off the coast of Mersing, Johor (N 2³8' 59' and E $103^{\circ} 52^{\prime} 41^{\prime \prime}$ ) and nearly $4 \mathrm{~km}$ to the southwest of Pulau Seri Buat, Pahang. These islands are uninhabited and the only permanent structure on the islands is a light tower on top of Pulau Mertang Barat, although there have been reports of turtle nesting activities on these islands (Mortimer 1990). Pulau Mertang has no marine park protected status, therefore visitors and fishing pressure are not controlled or monitored. They are also occasionally visited by tourists and scuba divers from Pahang and Johor. Therefore, there has been a proposal for Pulau Mertang to be gazetted under the Sultan Iskandar Marine Park (TLSI) recently as an effort to prevent potential loss of marine resources and to reduce damage caused by anthropogenic pollution, boating activities and recreational activities in the area (Department of Fisheries Malaysia 2019). Up to date, there is no study on the reef communities or coral biodiversity on these islands. Thus, the objectives of this study were to determine the coral and benthic community cover of Pulau Mertang as well as the diversity and distribution of benthic lifeforms of Pulau Mertang.

\section{MATERIALS AND METHODS}

\section{FIELD SAMPLING}

Fieldwork was conducted from July to August 2018 at nine random-picked reef sites around Pulau Mertang islets, three sites for each of the islands (Figure 1), using point intercept transect following the method outlined by Hils (2013) and Manuputty and Djuwariah (2009). All surveys were conducted during neap tides. Surveys were carried out using a $50 \mathrm{~m}$ long transect tape, positioned perpendicular from the islands at the depth of $2 \mathrm{~m}( \pm 0.5$ $\mathrm{m})$. Two transect lines were used at each reef site, with a $10 \mathrm{~m}$ interval parallel to each other. An underwater camera was also used to photograph the benthic communities and substrates along the transect lines to help with further coral identification. Data on sessile benthic lifeforms or substrate types for every $1 \mathrm{~m}$ mark were recorded alongside with hard corals found at $0.25 \mathrm{~m}$ of either side of the transect. All corals were identified to the generic level by using pictorial guides by Kelly (2016) and Sprung (1999) as references for identification. For a coral colony that comprises both dead and living tissues, the dead tissue was recorded as 'dead coral' and the living tissue was identified to genus level, as suggested by Beenaerts and Berghe (2005). The benthic communities were separated into six major categories; namely scleractinian corals, non-scleractinian corals, dead corals, algae, other biotic elements (sponges) and other abiotic elements (sands, rocks).

\section{DATA ANALYSIS}

Ecological parameters such as live coral cover (LCC), coral genus richness, population density and relative abundance were also determined. Reef health was further described using mortality index (MI) and coral morphology categories. The LCC was classified based on the percentage cover of live scleractinian and non-scleractinian corals based on Chou et al. (1994), where the LCC were

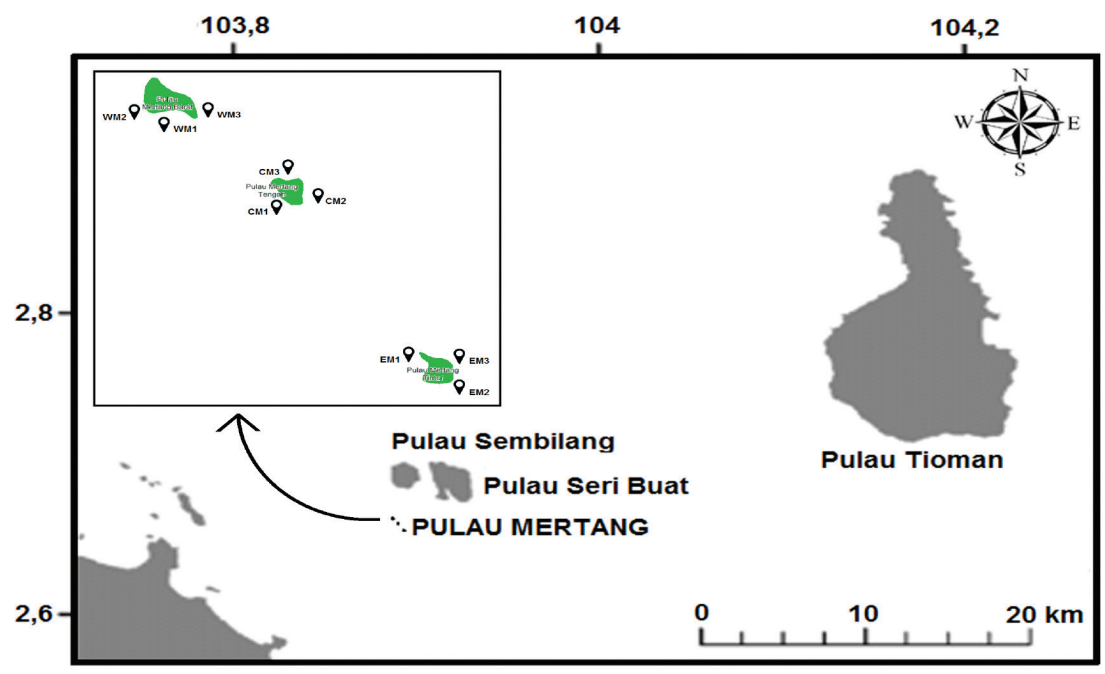

FIGURE 1. Map showing nine sampling locations in Pulau Mertang 
characterized in percentage (76-100\% as excellent, $51-75 \%$ as good, $26-50 \%$ as fair, and $0-25 \%$ as poor) and are used as an indication of the coral reef health. The coral genus richness was counted as the number of its colony present under the transect line.

The community analysis was carried out by finding the relative abundance (RA) values of each colony (Rilov \& Benayahu 1998):

$$
\mathrm{RA}=(\mathrm{Pi} / \mathrm{P} \text { total }) \times 100
$$

where $\mathrm{Pi}$ is pooled living coverage of the $\mathrm{i}^{\text {th }}$ species from all transects at a given site; $\mathrm{P}$ total is pooled total living coverage of all species in all transects at a given site. The values used for abundance categories (\%) are represented with ' $*$ ' as follows: not recorded $(\mathrm{RA}=0)$ as '-', rare $(0<\mathrm{RA}<0.1)$ as '*', uncommon $(0.1<\mathrm{RA}<1)$ as '**', common $(1<\mathrm{RA}<10)$ as ' $* * *$ ', abundant $(10<\mathrm{RA}<20)$ as '****', and dominant (RA>20) as ‘*****'. The population density was calculated as number of individual colonies per unit area, while the Shannon-Wiener diversity index was calculated on the number of the hard coral genera (Beenaerts \& Berghe 2005) in conjunction with the Evenness test.

Coral mortality index for each site was calculated as ratios of dead coral cover to the total cover of both live and dead corals (Gomez et al. 1994), where reefs with mortality index more than 0.33 is considered high 'in mortality' and classified as sick. Reef communities were classified following the method outlined by Edinger and Risk (2000), where the reefs classifications were plotted on the r-K-S ternary diagram according to the relative abundance of standardized coral morphology categories (Table 1). Data from this survey were summarized using basic univariate statistics such as mean and standard deviations.

\section{RESULTS}

\section{COVERAGE OF CORALS AND BENTHIC COMMUNITIES}

A total of 18 transects were undertaken at the reef around Pulau Mertang. The live corals and other substrates categories recorded and their occurrence at all nine sites are listed in Table 2. The mean live coral cover (LCC) (scleractinian coral cover + non-scleractinian coral cover) for Pulau Mertang was good at $51.05 \pm 2.35 \%$, with a range from $36.72 \%$ to $76.12 \%$. Reef site WM3 in Pulau Mertang Barat was categorized as having excellent coral cover $(76.12 \%)$, while reef site WM1 in the same island has the lowest live coral cover $(36.72 \%)$. Two out of three reef sites in Pulau Mertang Timur and one out of three reef sites in Pulau Mertang Tengah (EM1, EM3 and CM3) exhibited 'good' coral condition, whereas the other two reef sites in Mertang Tengah indicated a 'fair' coral condition. Nevertheless, the corals of Pulau Mertang Barat exhibit the best condition when compared to the other two islands. Extensive coral reefs were observed in the shallow channel between Pulau Mertang Barat and Pulau Mertang Tengah. The reefs appear to be in good condition with very little damage.

Overall, non-scleractinian coral in Pulau Mertang was observed to be dominated by zoanthids (Zoanthus sp.), while fauna other than corals was low. These groups were observed to be dominated by sponges $(6.76 \%)$. The percentage cover of the abiotic component of transect was dominated by recently dead corals $(15.19 \%)$. The high percentage of dead corals points to existence of healthy coral growth in the recent past. This followed by sand $(15.16 \%)$ which was also a common substrate type, and algae-covered dead corals at $13.79 \%$. The corals and other substrate categories recorded and their occurrence at the three islets are listed in Figure 2.

TABLE 1. Coral morphology categories used in reef surveys adapted following Edinger and Risk (2000)

\begin{tabular}{llc}
\hline Morphology & Description & rKS group \\
\hline Acropora & $\begin{array}{l}\text { Branching, bottlebrush, corymbose, digitate, tabular, and } \\
\text { submassive Acropora. }\end{array}$ & $\mathrm{r}$ \\
Tabular coral (non-Acropora) & Tabular non-Acropora, esp. Montipora & $\mathrm{r}$ \\
Millepora and Heliopora & Various species of Millepora \& blue coral (hydrocoral) & $\mathrm{r}$ \\
Branching coral & Branching non-Acropora corals; esp. Porites cylindrical, & $\mathrm{K}$ \\
Some other spp. & $\mathrm{K}$ \\
Foliose coral & Low relief, often small colonies & $\mathrm{K}$ \\
Mushroom coral & $\begin{array}{l}\text { Foliose, either horizontal or vertical, non-Acropora, esp. } \\
\text { Massive-platy coral }\end{array}$ & $\mathrm{K}$ \\
Massive coral & Free-living fungoid corals & $\mathrm{S}$ \\
Submassive coral & Plate-like corals forming large massive colonies, esp. & \\
& Euphyllia, Lobophyllia spp. & $\mathrm{S}$ \\
\hline
\end{tabular}


TABLE 2. Substrate composition percentage according to each surveyed sites from all islands at Pulau Mertang

\begin{tabular}{|c|c|c|c|c|c|c|c|c|}
\hline Reef Site & $\mathrm{SC}$ & $\mathrm{NC}$ & DC & $\mathrm{AC}$ & $\mathrm{Sp}$ & $\mathrm{Sd}$ & $\mathrm{Rc}$ & $\begin{array}{c}\text { Coral } \\
\text { condition }\end{array}$ \\
\hline \multicolumn{9}{|c|}{ Mertang Timur } \\
\hline EM1 & 35.65 & 25.22 & 9.57 & 15.65 & 0 & 13.91 & 0 & Good \\
\hline EM2 & 28.78 & 15.11 & 10.07 & 23.74 & 4.32 & 17.99 & 0 & Fair \\
\hline EM3 & 52.04 & 0 & 27.55 & 10.20 & 0 & 10.20 & 0 & Good \\
\hline Average & $38.82 \pm 9.76$ & $13.44 \pm 10.36$ & $15.73 \pm 8.36$ & $16.53 \pm 5.56$ & $1.44 \pm 2.03$ & $14.03 \pm 3.18$ & 0 & Good \\
\hline \multicolumn{9}{|c|}{ Mertang Tengah } \\
\hline CM1 & 45.83 & 0 & 2.78 & 11.11 & 2.78 & 36.11 & 1.39 & Fair \\
\hline $\mathrm{CM} 2$ & 37.40 & 8.40 & 28.24 & 25.95 & 0 & 0 & 0 & Fair \\
\hline CM3 & 48.54 & 4.85 & 20.39 & 2.91 & 4.85 & 16.50 & 1.94 & Good \\
\hline Average & $43.93 \pm 4.74$ & $4.42 \pm 3.44$ & $17.14 \pm 10.65$ & $13.33 \pm 9.54$ & $2.54 \pm 1.99$ & $17.54 \pm 14.76$ & $1.11 \pm 0.82$ & Fair \\
\hline \multicolumn{9}{|c|}{ Mertang Barat } \\
\hline WM1 & 35.16 & 1.56 & 17.97 & 21.88 & 3.13 & 15.63 & 4.69 & Fair \\
\hline WM2 & 35.82 & 8.96 & 18.66 & 0.75 & 9.70 & 23.13 & 2.99 & Fair \\
\hline WM3 & 76.12 & 0 & 1.49 & 11.94 & 7.46 & 2.99 & 0 & Excellent \\
\hline Average & $49.03 \pm 19.16$ & $3.51 \pm 3.91$ & $12.71 \pm 7.93$ & $11.52 \pm 8.63$ & $6.76 \pm 2.73$ & $13.91 \pm 8.31$ & $2.56 \pm 1.94$ & Good \\
\hline $\begin{array}{l}\text { Total } \\
\text { Average }\end{array}$ & $43.93 \pm 4.17$ & $7.12 \pm 4.48$ & $15.19 \pm 1.85$ & $13.79 \pm 2.07$ & $3.58 \pm 2.29$ & $15.16 \pm 1.68$ & $1.22 \pm 1.05$ & Good \\
\hline
\end{tabular}

Notes: $\mathrm{SC}=$ Scleractinian Corals $; \mathrm{NC}=$ Non-scleractinian Corals; $\mathrm{DC}=$ Dead Corals $; \mathrm{AC}=$ Algae-covered $; \mathrm{Sp}=\mathrm{Sponges} ; \mathrm{Sd}=\mathrm{Sands} ; \mathrm{Rc}=\mathrm{Rocks}$.

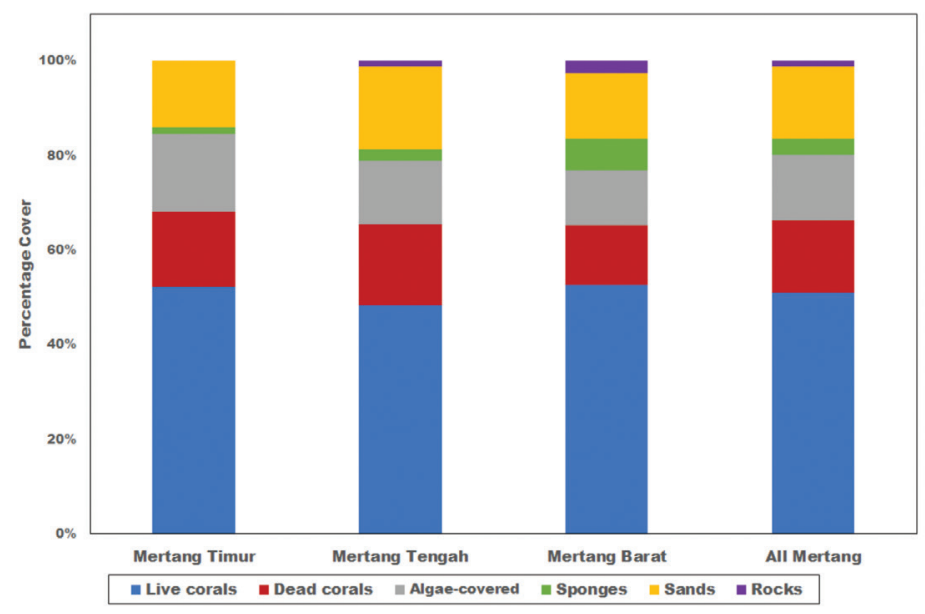

FIGURE 2. Percentage coverage of live corals and other benthic substrates at Pulau Mertang

\section{DIVERSITY AND DISTRIBUTION OF CORAL LIFEFORMS}

Scleractinians monopolized the reef fauna along all transects, except for site EM1. A total of 25 different genera from 12 families of scleractinian corals, and 4 genera of non-scleractinian corals were observed during this survey (Table 3). Coral diversity and density are higher at Pulau Mertang Barat compared to the other two islets. Family Acroporidae was the most dominant with a mean coverage of $55.50 \pm 22.53 \%$, followed by Fungiidae $(11.80 \pm 7.70 \%)$ and Poritidae $(9.52 \pm 8.74 \%)$.

For coral genus richness, EM3 and CM1 reef sites achieved the lowest record with 4 genera, respectively, and the highest from WM3 reef site with 18 genera recorded. Acropora was by far the most dominant scleractinian coral in terms of frequency occurrence with average of $41.26 \pm 20.88 \%$, followed by Montipora (14.24 $\pm 21.57 \%)$, Fungia $(11.23 \pm 7.43 \%)$, and Porites $(9.36 \%$ $\pm 8.71 \%$ ) which were also well represented in all reef sites. The colony of Acropora was considered abundant in all islands of Mertang, while the colony of Montipora was considered abundant only in Pulau Mertang Timur. Several site-specific differences for coral colonies are also noted in this study. Fungia is found in great abundance in the southern part of Pulau Mertang Timur with percentage cover of $23.26 \%$, while the western part of the island has extensive area covered by the zoanthids $(32.99 \%)$. 
TABLE 3. Distribution and relative abundance (RA) of coral colonies of Pulau Mertang

\begin{tabular}{|c|c|c|c|c|}
\hline No & Coral Genera & Mertang Timur & Mertang Tengah & Mertang Barat \\
\hline & \multicolumn{4}{|c|}{ SCLERACTINIAN CORALS } \\
\hline & \multicolumn{4}{|l|}{ Acroporidae } \\
\hline 1 & Acropora & $* * * * *$ & $* * * * *$ & $* * * * *$ \\
\hline \multirow[t]{2}{*}{2} & Montipora & $* * * * *$ & - & $* * *$ \\
\hline & Agariciidae & & & \\
\hline 3 & Pachyseris & - & - & $* *$ \\
\hline \multirow[t]{2}{*}{4} & Pavona & $* * *$ & $* *$ & - \\
\hline & Dendrophylliidae & & & \\
\hline 5 & Turbinaria & $* *$ & $* *$ & $* *$ \\
\hline \multirow[t]{2}{*}{6} & Tubastrea & - & - & $* * *$ \\
\hline & Euphyllidae & & & \\
\hline 7 & Euphyllia & $* *$ & - & - \\
\hline \multirow[t]{2}{*}{8} & Physogyra & - & - & $* * *$ \\
\hline & Faviidae & & & \\
\hline 9 & Echinopora & $* *$ & $* * *$ & - \\
\hline 10 & Favia & - & $* *$ & $* *$ \\
\hline 11 & Favites & $* *$ & $* *$ & $* *$ \\
\hline 12 & Goniastrea & $* *$ & $* *$ & - \\
\hline \multirow[t]{2}{*}{13} & Platygyra & $* *$ & $* *$ & $* * *$ \\
\hline & Fungiidae & & & \\
\hline 14 & Fungia & $* * *$ & $* * *$ & $* * * *$ \\
\hline 15 & Herpolitha & $* *$ & $* *$ & $* *$ \\
\hline \multirow[t]{2}{*}{16} & Heliofungia & - & - & $* *$ \\
\hline & Merulinidae & & & \\
\hline \multirow[t]{2}{*}{17} & Merulina & - & - & $* *$ \\
\hline & Mussidae & & & \\
\hline 18 & Lobophyllia & $* *$ & - & $* *$ \\
\hline \multirow[t]{2}{*}{19} & Symphyllia & $* *$ & - & $* *$ \\
\hline & Oculinidae & & & \\
\hline \multirow[t]{2}{*}{20} & Galaxea & $* *$ & $* * *$ & $* * *$ \\
\hline & Pectiniidae & & & \\
\hline 21 & Echinophyllia & - & $* *$ & $* *$ \\
\hline \multirow[t]{2}{*}{22} & Pectinia & $* *$ & $* * *$ & $* * *$ \\
\hline & Pocilloporidae & & & \\
\hline \multirow[t]{2}{*}{23} & Pocillopora & $* * *$ & $* * *$ & $* * *$ \\
\hline & Poritidae & & & \\
\hline 24 & Goniopora & - & $* *$ & $* *$ \\
\hline \multirow[t]{3}{*}{25} & Porites & $* * *$ & $* * *$ & $* * * *$ \\
\hline & No. of Sighted Genera & 17 & 16 & 21 \\
\hline & NON-SCLERACTINIAN & & & \\
\hline 26 & Dendronephthya & - & - & $* *$ \\
\hline 27 & Junceella & - & $* * *$ & $* * *$ \\
\hline 28 & Rhodactis & - & $* *$ & $* *$ \\
\hline \multirow[t]{2}{*}{29} & Zoanthus & $* * * *$ & $* * *$ & - \\
\hline & No. of Sighted Genera & 1 & 3 & 3 \\
\hline
\end{tabular}

-not recorded, $*$ rare, $* *$ uncommon, ${ }^{* * *}$ common, $* * * *$ abundant, $* * * * *$ dominant 
Montipora, although found abundance in Pulau Mertang Timur and Pulau Mertang Barat, was absent in Pulau Mertang Tengah. Porites was found to be more abundant in Pulau Mertang Barat (19.49\%) than the other two islands $(5.05 \%$ at Pulau Mertang Tengah and $3.54 \%$ at Pulau Mertang Timur). The ahermatypic coral, Tubastrea and soft corals, Dendronephthya were only observed at Pulau Mertang Barat, but none was observed at other islands.

The most abundant growth forms of all live corals (scleractinian coral + non-scleractinian coral) were branching $(46.01 \pm 20.92 \%)$, followed by thin plates and crusts $(15.98 \pm 21.13 \%)$ and massive/thick colonies $(13.11 \pm 9.05 \%)$ as shown in Table 4 . The meandering ridges and valleys form was the most poorly represented $(3.61 \pm 3.85 \%)$. All the dominant genera, with the exception of Fungia, occur exclusively as branching, thin plates and massive forms. The colonies of Fungia were mainly represented as solitary $(11.80 \pm 7.70 \%)$. For nonsclerectinian corals, the coverage is only $9.49 \pm 11.17 \%$ from the total coral cover.

TABLE 4. Coverage of live coral growth forms at Pulau Mertang, as a percentage of total coral cover

\begin{tabular}{lc}
\hline Growth Form & Percentage Cover $(\%)$ \\
\hline Branching & $46.01 \pm 20.92$ \\
Meandering Ridges \& Valleys & $3.61 \pm 3.85$ \\
Massive / Thick Colonies & $13.11 \pm 9.05$ \\
Thin Plates \& Crusts & $15.98 \pm 21.13$ \\
Solitary / Isolated & $11.80 \pm 7.70$ \\
Non-Scleractinian Corals & $9.49 \pm 11.17$ \\
\hline
\end{tabular}

The Shannon-Wiener index was calculated to give a better understanding of the diversity of the reefs. Coral genus diversity was highest at Pulau Mertang Barat (H' = 2.24), followed by Pulau Mertang Timur ( $\left.\mathrm{H}^{\prime}=1.71\right)$ and Pulau Mertang Tengah (H'=1.56) (Table 5). Subsequently, Pulau Mertang Tengah also has the lowest evenness index among all three islets with the value of 0.56 . All islands show low values of mortality index $(\mathrm{MI}<0.33)$, where the average MI for Pulau Mertang was 0.23 indicating good condition of the reef.

Figure 3 shows the coral morphology class score for nine reef sites of Pulau Mertang. Most of the reefs sites (EM1, EM3, CM1, CM2, CM3, WM3) was classified as class 3 (C3) and displayed ruderal coral morphologies. Three

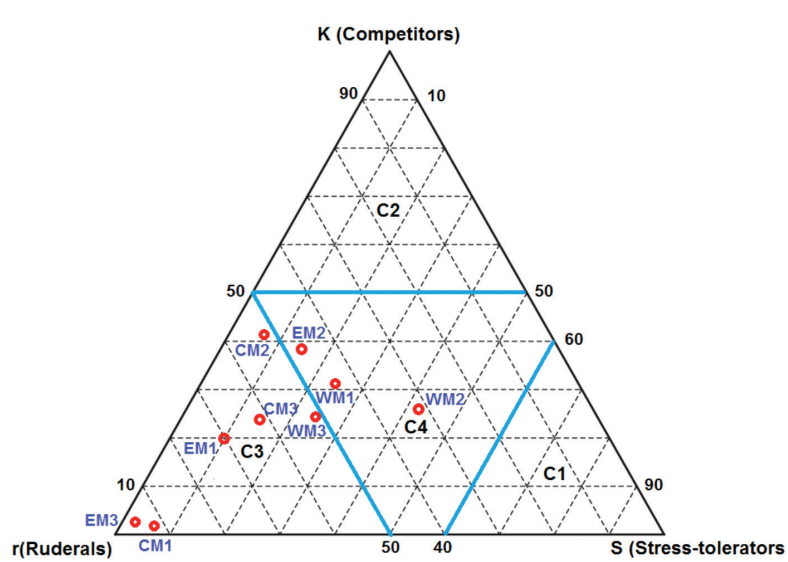

FIGURE 3. Coral morphology class score for nine reef sites in Pulau Mertang

reef sites were classified as class 4 (C4); two of them were sites from Pulau Mertang Barat.

\section{DISCUSSION}

The live coral coverage (LCC) OF Pulau Mertang is lower compared to Pulau Tioman (66.36\% in 2017) as reported by Reef Check Malaysia (2018), but it was higher than the LCC for Pulau Seri Buat (48.2\%) (Harborne et al. 2000) and the average LCC for Malaysia (42.5\%) (Reef Check Malaysia 2018). However, the diversity is low when compared to other nearby reefs in the region, such as Pulau Tioman with 57 genera from 17 families (Shahbudin et al. 2017). Nevertheless, the dominant genera (Acropora and Montipora) found at Pulau Mertang is generally consistent with the dominant genera (Acropora and Montipora) for Tioman and Seri Buat reefs (Harborne et al. 2000; Kamarumtham et al. 2016; Shahbudin et al. 2017; Toda et al. 2007).

All indices of reef health considered here, i.e. live coral cover, coral genus richness, population density, coral diversity, mortality index, and coral morphology categories, agreed on what constitutes as a healthy reef; domination by branching and tabular Acropora $(\mathrm{CC}=3)$, high complexity (high H'), high live coral cover (good condition), and a low ratio of dead to live corals (MI < 0.33). Nonetheless, Pulau Mertang has a relatively high percentage of abiotic materials (sand and rocks) and dead corals; similar to the percentage of non-coralline algae (15.6\%) recorded at Pulau Seri Buat (Harborne et al. 2000)

TABLE 5. Shannon-Wiener Diversity Index (H'), Evennes Index and Coral Mortality Index (MI) of coral lifeforms in Pulau Mertang

\begin{tabular}{lccc}
\hline & H'$^{\prime}$ & Evenness & MI \\
\hline P. Mertang Timur & 1.71 & 0.60 & 0.23 \\
P. Mertang Tengah & 1.56 & 0.56 & 0.26 \\
P. Mertang Barat & 2.24 & 0.73 & 0.19 \\
All Islands & 2.08 & 0.65 & 0.23 \\
\hline
\end{tabular}


which indicates that these islands were subjected to high sediment load. Pulau Mertang and Pulau Seri Buat are relatively close to the mainland and the high sedimentation regime could be due to sewage runoff and coastal development. This might attribute to the dominance of zoanthids, where these Zoanthus specimens were mostly found on dead corals, sometimes blanketing a huge area of coral rubbles (Wee et al. 2015). Wee et al. (2015) also found out that Zoanthus are capable of producing monospecific 'zoanthid zones' (zoanthid benthic cover $>50 \%$ ). Hence, explaining the wide spread distribution of zoanthids.

Branching Acropora tends to be found or is dominant in ruderals, as this type of coral have high growth rates and expand more rapidly but are very susceptible to breakage and has lower tolerance to sedimentation (Loke et al.2013; Toda et al. 2007; Unsworth et al. 2010). Lee and Mohamed (2011) reported that the east coast of Peninsular Malaysia received high accumulations rate of settling particles in certain times of the year caused by high energy seasonal wave and monsoon, whereas Loke et al. (2016) reported that growth trend of Acropora was possibly related to the annual monsoon seasons in Malaysia. Most of the reef sites in Pulau Mertang need to be conserved since most reef sites are classified as ruderals, which showed that reefs of Pulau Mertang may be more susceptible to changes in environmental parameters, such as currents, wave actions, and fluctuation of suspended sediment concentrations. As two of three reefs at Pulau Mertang Barat received class 4 (C4) categories, it is suggested that these sites had the highest coral species diversity and habitat complexity, and thus they are most likely to provide optimum conditions for fish habitat and maximum fisheries potential. Edinger and Risk (2000) concluded that reef communities with the higher conservation class (C4) harbor more species diversity and habitat complexity compared to the lower classes, which is concurrent with the results that Pulau Mertang Barat has the highest value in term of species richness. The differences in distribution of corals at the three islands could be indicative of differences in reef morphology, current regimes and other physical parameters, which will be looked into in future studies. Up to date, no previous survey has been conducted on this island and thus, no literature reviews have been found. Thus, this study forms an initial step in understanding the coral community and provides a basis for future observations on the coral ecosystem of Pulau Mertang.

\section{CONCLUSION}

This study concluded that the reefs around Pulau Mertang were in good condition, constitutes a healthy reef, based on the r-K-S group classification. These reefs are significant from an ecological point of view as it is the closest representation of an undisturbed reef of a non-marine park island in Johor. Thus, substantial steps should be taken to conserve and protect these coral reefs.

\section{ACKNOWLEDGEMENTS}

The authors wish to thank the staffs of Tunku Abdul Rahman Aquarium (AkuaTAR) and EKOMAR, Universiti Kebangsaan Malaysia for making this project possible. Funding support was provided through the Resource Management Division, Department of Fisheries (DoF) development budget of 2018. The assistance of Dr. Mohammad Rozaimi bin Jamaludin (UKM), Mr.Zaidnuddin bin Ilias (FRI Langkawi), Mr. Dzulfikar bin Baitul Ma'mur (AkuaTAR) and Mr. Mohd Nazuri Rudin bin Jali (Johor State Fisheries) is greatly acknowledged.

\section{REFERENCES}

Affendi, Y.A. \& Rosman, F.R. 2012. Current knowledge on scleractinian coral diversity of Peninsular Malaysia. In Malaysia's Marine Biodiversity: Inventory and Current Status, edited by Kamarruddin, I., Mohamed, C.A.R., Rozaimi, M.J., Kee Alfian, A.A., Fitra, A.Z. \& Lee, J.N. Putrajaya: Department of Marine Park Malaysia. pp. 21-31.

Akmal, M.F.K., Shahbudin, S. \& Yusof, M.H. 2014. Diversity and distribution of scleractinian and non-scleractinian corals at selected areas in Tioman Island, Malaysia. 3rd International Conference on Applied Life Sciences (ICALS2014). Bangi, Selangor. 18th-20th September.

Beenaerts, N. \& Berghe, E.V. 2005. Comparative study of three transect methods to assess coral cover, richness and diversity. Western Indian Ocean J. Mar. Sci. 4(1): 29-37.

Chou, L.M., Wilkinson, C.R., Licuanan, W.R.Y., Alino, P., Cheshire, A.C., Loo, M.G.K., Tangjaitrong, S., Ridzwan, A.R. \& Soekarno. 1994. Status of coral reefs in the ASEAN region. In Proc. Third ASEAN-Australia Symp. on Living Coastal Resources, edited by Sudara, S., Wilkinson, C.R. \& Chou, L.M. 1: 1-10.

Costanza, R., DeGroot, R., Sutton, P., Ploeg, S.V.D., Anderson, S.J., Kubiszewski,I., Farber, S. \& Turner, R.K. 2014. Changes in the global value of ecosystem services. Glob. Environ. Change 26: 152-158.

Department of Fisheries Malaysia. 2019. Dokumen konsultasi bagi cadangan pewartaan perairan tujuh (7) buah pulau iaitu Mertang Barat, Mertang Tengah, Mertang Timur, Lima Kechil, Lima Besar, Tokong Rakit, Tokong Yu dan empat (4) buah batuan iaitu Tokong Gantang, Tokong Condong, Tokong Belalai dan Tokong Chupak sebagai Taman Laut Sultan Iskandar di bawah Seksyen 41, Akta Perikanan 1985 (Akta 317).

Edinger, E.N. \& Risk, M.J. 2000. Reef classification by coral morphology predicts coral reef conservation value. Biol. Conserv. 92: 1-13.

Gomez, E.D., Alino, P.M., Yap, H.T. \& Licuanan, W.Y. 1994. A review of the status of Philippines reefs. Mar. Poll. Bull. 29: $62-68$

Grismer, L.L., Youmans, T.M., Wood Jr., P.L. \& Grismer, J.L. 2006. Checklist of the herpetofauna of the Seribuat Archipelago, West Malaysia with comments on biogeography, natural history and adaptive types. The Raffles Bulletin of Zoology 54(1): 157-180.

Harborne, A., Fenner, D., Barnes, A., Beger, M., Harding, S. \& Roxburgh, T. 2000. Status Report on the Coral Reefs of the East Coast of Peninsular Malaysia. Kuala Lumpur: Department of Fisheries Malaysia. 
Huang, D., Licuanan, W.Y., Hoeksema, B.W., Chen, C.A., Ang, P.O., Huang, H., Lane, D.J.W., Vo, S.T., Waheed,Z., Affendi, Y.A., Yeemin, T. \& Chou, L.M. 2015. Extraordinary diversity of reef corals in the South China Sea. Marine Biodiversity 45(2): $157-168$

Hils, A.L. 2013.Acomparison of methods for improving ecological monitoring of coral reefs. Master of Environmental Science dissertation. University of Miami, Ohio (Unpublished).

Kamarumtham, K., Ahmad, Z., Halid, N.H., Shahbudin, S., Akmal, M.F.K., Shahbudin, S., Yusof, M.H. \& Hanafiah, M.F.M. 2016. Diversity and distribution of coral lifeforms in Tioman Island. Transactions on Science and Technology 3(2-2): 367-373.

Kelley, R. 2016. Indo-Pacific Coral Finder. 3rd ed. BYO Guides: Townsville.

Kimura, T., Tun, K. \& Chou, L.M. 2014. Status of Coral Reefs in East Asian Seas Region:2014. Ministry of the Environment, Japan.

Lee, J.N. \& Mohamed, C.A.R. 2011. Accumulation of settling particles in some coral reef areas of Peninsular Malaysia. Sains Malaysiana 40(6): 549-554.

Loke, H.X., Cheliah, A., Chen, S.Y., Hyde, J., Zaidi, C.C. \& Adzis, K.A.A. 2013. Comparison of Acropora formosa coral growth in natural habitat condition between Tioman Island and Pangkor Island, Malaysia. Journal of Science and Technology in the Tropics 9: 31-45.

Loke, H.X., Adzis, K.A.A., Hyde, J. \& Zaidi, C.C. 2016. Growth performance of Acropora formosa in natural reefs and coral nurseries for reef restoration. AACL Bioflux 9(5): 1090-1100.

Manuputty, A.E.W. \& Djuwariah. 2009. Point Intercept Transect (PIT) for Community: Base Line Study and Coral Health Monitoring at Marine No Take Zone Area (DPL). COREMAP II - LIPI. Jakarta.

Mortimer, J.A. 1990. A Report on the Turtle Populations of the Islands Off the East Coast of Johor and Suggestions for Their Management. WWF Project 3868. WWF Malaysia.

Mustapha, M.A., Lihan, T. \& Khalid, L.I. 2014. Coral reef and associated habitat mapping using ALOS satellite imagery. Sains Malaysiana 43(9): 1363-1371.

Reef Check Malaysia. 2018. Status of Coral Reefs in Malaysia, 2017. Reef Check Malaysia.
Rilov, G. \& Benayahu, Y. 1998. Vertical artificial structures as an alternative habitat for coral reef fishes in disturbed environments. Mar. Env. Res. 45: 431-451.

Shahbudin, S., Fikri Akmal, K., Faris, S., Normawaty, M.N. \& Mukai, Y. 2017. Current status of coral reefs in Tioman Island, Peninsular Malaysia. Turk. J.Zool. 41: 294-305.

Sprung, J. 1999. Corals: A Quick Reference Guide. Ricordea Publishing: Miami.

Toda, T., Okashita, T., Maekawa, T., Abdul Aziz, K.A., Mohd Khusairi, M.R., Nakajima, R.,Chen, W., Takahashi, K.T.,Haji Ross, O.\& Terazaki, M. 2007. Community structures of coral reefs around Peninsular Malaysia.J. Oceanogr. 63: 113-123.

Unsworth, R.K.,Clifton, J. \& Smith, D.J. 2010. Marine Research and Conservation in the Coral Triangle: The Wakatobi National Park. New York: Nova Science Publisher.

Wee, H.B., Liew, H.C.,Zainudin, B . \& Reiner, J.D. 2015. Vertical distribution of zooxanthellae zoantharians on coral reefs of Terengganu Islands, Malaysia. Platax 12: 29-37.

Mohamad Saupi Ismail

Akuarium Tunku Abdul Rahman

Fisheries Research Institute

11960 Batu Maung, Pulau Pinang

Malaysia

Khoo Mei Ling*

Centre of Ecosystem Management and Natural Resources (PPESS)

Faculty of Science and Technology, Universiti Kebangsaan Malaysia

43600 Bangi, Selangor Darul Ehsan

Malaysia

*Corresponding author; email: meilingkhoo@ukm.edu.my

Received: 1 April 2019

Accepted: 15 August 2019 